\title{
Effect Of Financial Innovations On Performance Of Microfinance Institutions In Nakuru Town, Kenya
}

\author{
Kibugo, Martin Kabiro ${ }^{1}$, Dr. Kimani Maina ${ }^{2}$ \\ ${ }^{1 .}$ Corresponding Author, MBA Student, Jomo Kenyatta University of Agriculture and Technology, Kenya \\ 2. Lecturer, Jomo Kenyatta University of Agriculture and Technology, Kenya.
}

\begin{abstract}
Innovation is described as the process by which, firms master and implement design, and the production of goods and services that are new to them. Innovations generally assume different forms such as product innovations, marketing innovations, micro MFIS, location innovation, and research and development innovation. Financial innovations include institutional innovation, product innovation, and process innovation. These innovations have eased the way of doing business for financial institutions including microfinance institutions. It remains largely unclear whether MFIs are adequately innovative in running their businesses given that they are faced by the challenge of limited growth and expansion. Performance and growth are related in that a firm cannot grow if it fails to post sound performance. The general objective of the study was to determine the effect of financial innovation on performance of microfinance institutions in Kenya. Specific objectives include examining the effect of institutional innovation, product innovation, and process innovation on performance of microfinance institutions. The study was guided by theory of induced institutional innovation, demand-supply theory of innovation, theory of innovation diffusion, and economic value added theory. Descriptive survey research design was used in this study. The target population comprised of all employees working with MFIs registered with AMF-Kenya and the accessible populations were 187 employees working with MFIs registered with AMF in Nakuru town, Kenya. Samples of 70 respondents were drawn from the study population using stratified random sampling technique. The study used questionnaire as the tool for primary data collection. Secondary data was collected using a data collection sheet. A pilot study was conducted before the main study with the aim of determining the reliability and validity of the research instrument. The study determined the validity of the questionnaire by use of content validity test. Reliability was tested using the Cronbach alpha coefficient. Data processing and analysis was facilitated by the use of the Statistical Package for Social Sciences. Data analysis encompassed both descriptive statistics and inferential statistics. Descriptive statistics such as means, mode, standard deviations, and variance was used. On the other hand, inferential statistics was in form of Pearson's correlation coefficient, and multiple regression analysis. The result of the analysis was presented in form of tables, charts, and graphs. From the findings, the research concluded that there is a supervisory framework that monitors MFIs. Some of the innovations observed by MFIs in mobile banking include partnerships, financial trainings, branch networking and opening up new branches. It is was also concluded that innovations can be a source of competitive advantage if a firm understands customer needs, competitors' actions and technological development and act accordingly to stay at par with rivals. The study recommended that in-order to enhance firm performance the management of microfinance ought to focus on the firm activities aligned towards renewing routines, procedures and processes in an innovative manner in a firm. This will positively improve the performance of microfinance.
\end{abstract}

Keywords: Financial Innovation, Microfinance, institutional innovations, product innovations, process innovations

\section{Introduction}

Innovation is described as the process by which, firms master and implement design, and the production of goods and services that are new to them regardless of whether they are new to their competitors, country or the world (Mytelka, 2000). More so, Spielman (2005) defines innovation as the continuous process of upgrading by employing new knowledge or the new combination of existing knowledge that is new to the local area. Innovations generally assume different forms such as product innovations, marketing innovations, micro MFIS, location innovation, and research and development innovation.

In particular, financial innovations include institutional innovation, product innovation, and process innovation (Lawrence \& Scott, 2001). Institutional innovations relate to changes in microfinance structures, establishment of new types of financial intermediaries, and changes in the legal and supervisory framework. Product innovations include the introduction of goods or services with improved characteristics to respond to changes in market demand or to improve the efficiency. These may include new credit cards, personal unsecured loans, money transfers services, mobile banking and mobile lending. Process innovations cover the introduction of new business processes leading to increased efficiency, market expansion and client data 
management. Process innovations include electronic banking, automated teller machines (ATMs) and Real Time Gross Settlement (RTGS). Financial innovations provide easy access to accurate activities like disbursements, repayments, deposits, withdrawals, and money transfer. As such, there are minimal opportunities for errors.

\section{Statement of the Problem}

The importance of financial innovations cannot be underrated. These innovations have eased the way of doing business for financial institutions including microfinance institutions (Ongwen, 2015). As a result of innovations, there can be greater outreach, for instance when technology is adopted in transacting business. Leading financial institutions such as commercial banks are very innovative in their institutionalization, products and processes which have resulted in improved performance. However, this has not been the case with MFIs in Kenya.

It remains largely unclear whether MFIs are adequately innovative in running their businesses given that they are faced by the challenge of limited growth and expansion. This is underscored by the fact that only 11 MFIs are hitherto registered with the Association of Microfinance Institution of Kenya (AMF-Kenya) as opposed to a total of 42 commercial banks registered with the Central Bank of Kenya (CBK). Performance and growth are related in that a firm cannot grow if it fails to post sound performance. MFIs have been around for decades and have primarily been serving the low cadre members of the society (EUI 2010). Against the backdrop of dynamics in the world today and advancement of technology in the financial sector, in addition to commercial banks providing microfinance services, MFIs have found themselves in an awkward position in terms of competition. This has threatened their very existence. The financial challenges facing MFIs have far reaching impact. These institutions employ thousands of Kenyans who are breadwinners in thousands of households across the country. As such, in the event that MFIs post poor performance and downsize their staff or close shop altogether, there are many Kenyans who would directly and indirectly be affected. More so, these firms pay taxes to the government through Kenya Revenue Authority and poor performance would translate to reduced tax remittances. The foregoing would definitely affect the revenue collection by the government. Various local scholars have examined the themes of financial innovation and performance. Kariuki's (2010) study noted that process innovation affected performance positively. However, the study focused on commercial banks as opposed to MFIs. A study by Mugo (2012) focused on MFI institutional innovativeness. However, the study did not link institutional innovation to performance. Chemitei (2012) investigating the role of innovation in creating competitive advantage in MFIs as opposed to performance. Mwangi (2014) studied the effect of financial innovation on financial returns of deposit taking MFIs in Kenya. Yet, the study was limited to deposit taking MFIs whereas majority of MFIs do not take deposits, rather they give out credit facilities. It's against the backdrop that this study will be carried to fill these research gaps.

\section{Objectives}

i. To examine the effect of institutional innovations on performance of microfinance institutions in Nakuru town.

ii. To assess the effect of product innovations on performance of microfinance institutions in Nakuru town.

iii. To analyze the effect of process innovations on performance of microfinance institutions in Nakuru town.

\section{Conceptual Framework}

The study was structured based on the conceptual framework shown below.

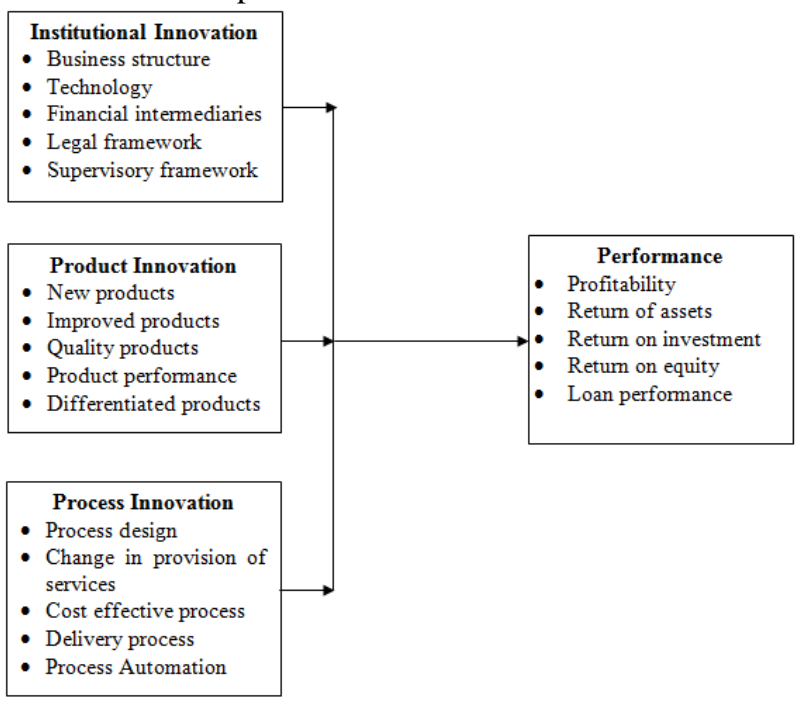




\section{Research Design}

\section{Methodology}

Descriptive survey research design was used in this study to assess the impact of financial innovations on the profitability of microfinance firms. The rationale for choosing this design is based on its ability to provide the researcher with appropriate techniques for a systematic collection of extensive data from a large group of respondent through administration of questionnaires (Orodho, 2009). This design was appropriate to the study because it enabled the investigator obtain information of the variable of the study in their natural settings and allow valid general conclusions from the facts discovered.

\section{Study Population}

The target population for this study consisted of all employees working with the microfinance institutions in Kenya. Accessible population constituted 187 employees working with MFIs in Nakuru town that have been registered with the Association of Microfinance Institutions - Kenya. There were 11 firms registered with the Association and employ 187 employees.

\section{Sampling Technique and Sample Size}

Nassiuma's (2008) formula was employed to determine the size of the sample as follows.

$$
n=\frac{N C^{2}}{C^{2}+(N-1) e^{2}}
$$

Where

n represents sample size,

$\mathrm{N}$ represents study population

$\mathrm{C}$ represents coefficient of variation $(21 \% \leq \mathrm{C} \leq 30 \%)$, and

e represents error margin $(2 \% \leq \mathrm{e} \leq 5 \%)$.

Calculating the sample size,

$$
\begin{array}{lll}
\mathrm{n} & = & \frac{187(0.21)^{2}}{0.21^{2}+(187-1) 0.02^{2}} \\
\mathrm{n} & = & 69.59 \\
\mathrm{n} & = & 70 \text { respondents }
\end{array}
$$

The size of the sample (n) was, therefore 70 respondents (employees). The respondents were drawn from the study population using stratified random sampling. This is due to the fact that the 11 MFIs in Nakuru town had different number of employees and this sampling method ensured proportionate participation of employees from all the MFIs. As shown in Table 1.

Table 1: Sample Distribution

\begin{tabular}{|l|l|l|}
\hline Microfinance Institutions & Accessible Population & Sample Size \\
\hline Vision Fund Kenya Limited & 13 & 5 \\
\hline BIMAS & 19 & 7 \\
\hline SISDO & 16 & 6 \\
\hline Eclof Kenya & 13 & 5 \\
\hline Pamoja Women Development Programme & 24 & 9 \\
\hline Real People & 11 & 4 \\
\hline Jitegemee Credit Scheme & 24 & 9 \\
\hline Micro Africa Ltd & 19 & 7 \\
\hline Fusion Capital Ltd & 13 & 5 \\
\hline Musoni Kenya Ltd & 16 & 6 \\
\hline Platinum Credit Limited & 19 & 7 \\
\hline Total & $\mathbf{1 8 7}$ & $\mathbf{7 0}$ \\
\hline
\end{tabular}

\section{Research Instrument}

The study used self-administered structured questionnaire as the tool for data collection. A questionnaire is a research instrument consisting of a series of questions and other prompts for the purpose of gathering information from respondents (Mugenda\&Mugenda, 2003). The use of questionnaire was also relatively quick in collecting information from the respondents. Additionally, potential information can be collected from a large portion of a group (Kothari, 2008). The questionnaire comprised of structured questions which was on a Likert scale of 5 points. Secondary data was collected using a secondary data collection sheet. A pilot study was conducted before the main study with the aim of determining the reliability and validity of the research instrument. The pilot study was conducted in Eldoret town where randomly selected MFIs had their employees participating in the pilot study. 


\section{Data Processing and Analysis}

The collected data was subjected to the relevant data cleaning, processing and analysis respectively. Data processing and analysis was facilitated by the use of the Statistical Package for Social Sciences (SPSS) Version 24 software. Data analysis encompassed both descriptive statistics and inferential statistics. Descriptive statistical tools which included means, mode, standard deviations, and variance were used. On the other hand, inferential statistics was in form of Pearson's correlation coefficient and multiple regression analysis. The result of the analysis were presented in form of tables, charts, and graphs. The following regression model guided the study.

$Y=\beta_{0}+\beta_{1} X_{1}+\beta_{2} X_{2}+\beta_{3} X_{3}+\varepsilon$

Where:

$\begin{array}{lll}Y & \text { is } & \text { Performance } \\ \beta_{0} & \text { is } & \text { Constant } \\ X_{1} & \text { is } & \text { Institutional Innovation } \\ X_{2} & \text { is } & \text { Product Innovation } \\ X_{3} & \text { is } & \text { Process Innovation } \\ \varepsilon & \text { is } & \text { Errorterm } \\ \beta_{1}, \beta_{2}, \beta_{3} & \text { are } & \text { Regression coefficients of Independent variables. }\end{array}$

The significance of the relationship between each of the three independent variables (institutional innovation, product innovation and process innovation) and performance of MFIs was determined using the ftest. The significance level was 0.05 . The contribution of the financial innovations towards performance of MFIs under study was determined using the coefficient of determination $\left(\mathrm{r}^{2}\right)$.

\section{Descriptive information on Institutional Innovation}

\section{Findings}

The respondents were asked to indicate their level of agreement on the effect of institutional innovation on the performance of microfinance. The findings were as indicated in Table 2

Table 2: Institutional Innovation on Performance of Microfinance Institution

\begin{tabular}{|c|c|c|c|c|c|c|c|c|}
\hline & $\begin{array}{l}\text { Strongly } \\
\text { Agree }\end{array}$ & Agree & Indifferent & Disagree & $\begin{array}{l}\text { Strongly } \\
\text { Disagree }\end{array}$ & Max & Min & Mean \\
\hline $\begin{array}{l}\text { MFIs have a clear business } \\
\text { structure. }\end{array}$ & $16(26)$ & $29(47)$ & $11(17)$ & $\begin{array}{ll}6 \quad(10)\end{array}$ & $\begin{array}{ll}0 & (0)\end{array}$ & 5 & 1 & 3.887 \\
\hline $\begin{array}{l}\text { MFIs have adopted advanced } \\
\text { technologies. }\end{array}$ & $23(37)$ & $27(45)$ & $8 \quad(13)$ & $3 \quad(5)$ & $\begin{array}{ll}0 & (0)\end{array}$ & 5 & 1 & 4.081 \\
\hline $\begin{array}{l}\text { MFIs have partnered with various } \\
\text { financial intermediaries. }\end{array}$ & $35(57)$ & $23(37)$ & $\begin{array}{ll}4 \quad(6)\end{array}$ & $0(0)$ & $\begin{array}{ll}0 & (0)\end{array}$ & 5 & 1 & 4.500 \\
\hline $\begin{array}{l}\text { MFIs are guided by a clear legal } \\
\text { framework }\end{array}$ & 24 (39) & $27(44)$ & $7 \quad(11)$ & $4 \quad(6)$ & $\begin{array}{ll}0 & (0)\end{array}$ & 5 & 1 & 4.145 \\
\hline $\begin{array}{l}\text { There is a supervisory framework } \\
\text { that monitors MFIs }\end{array}$ & $28(45)$ & $23(37)$ & $8 \quad(13)$ & $3 \quad(5)$ & $\begin{array}{ll}0 & (0)\end{array}$ & 5 & 1 & 4.226 \\
\hline
\end{tabular}

According to the findings, the respondents agreed that MFIs have a clear business structure with a mean of 3.887. They also indicated with a mean of 4.081 that MFIs have adopted advanced technologies. They further indicated with a mean of 4.500 that MFIs have partnered with various financial intermediaries. In addition, the respondents indicated with a mean of 4.145 that MFIs are guided by a clear legal framework. Finally, the respondents indicated with a mean of 4.226 that there is a supervisory framework that monitors MFIs. The study is in line with Mugo, (2012) that Institutional innovations are characterized by technology. He further stated that MFIs enjoy economies of scale and more so, using technology enable the institutions to cut down costs and reduce interest rates.

\section{Product Innovation on Performance of Microfinance Institution}

The study assessed the views of the respondents concerning product innovation and performance of microfinance institutions. The pertinent findings are illustrated in Table 3. 
Effect Of Financial Innovations On Performance Of Microfinance Institutions In Nakuru Town,..

Table 3: Product Innovation on Performance of Microfinance Institution

\begin{tabular}{|l|l|l|l|l|l|l|l|l|}
\hline & $\begin{array}{l}\text { Strongly } \\
\text { Agree }\end{array}$ & Agree & Indifferent & Disagree & $\begin{array}{l}\text { Strongly } \\
\text { Disagree }\end{array}$ & Max & Min & Mean \\
\hline $\begin{array}{l}\text { MFIs develop new } \\
\text { products quite regularly. }\end{array}$ & $32(52)$ & $24(39)$ & $6(9)$ & $0(0)$ & $0(0)$ & 5 & 1 & 4.419 \\
\hline $\begin{array}{l}\text { MFIs offer improved } \\
\text { products to their } \\
\text { customers. }\end{array}$ & $23(37)$ & $19(31)$ & $12(19)$ & $8(13)$ & $0(0)$ & 5 & 1 & 3.919 \\
\hline $\begin{array}{l}\text { MFIs offer high quality } \\
\text { services. }\end{array}$ & $27(44)$ & $25(40)$ & $4(6)$ & $6(10)$ & $0(0)$ & 5 & 1 & 4.177 \\
\hline $\begin{array}{l}\text { The product performance } \\
\text { is relatively high } \\
\text { compared to other } \\
\text { financial institutions. }\end{array}$ & $23(37)$ & $24(39)$ & $6(10)$ & $9(14)$ & $0(0)$ & 5 & 1 & 3.919 \\
\hline $\begin{array}{l}\text { The products offered by } \\
\text { MFIs are highly } \\
\text { differentiated. }\end{array}$ & $26(42)$ & $24(39)$ & $7(11)$ & $5(8)$ & $0(0)$ & 5 & 1 & 4.145 \\
\hline
\end{tabular}

According to the findings, the respondents indicated with a mean of 4.419 that MFIs develop new products quite regularly. The respondents further indicated with a mean of 3.919 that MFIs offer improved products to their customers. Also, they indicated with a mean of 4.177 that MFIs offer high quality services. Futher they indicated with a mean of 3.919 that the product performance is relatively high compared to other financial institutions. The respondents finally indicated with a mean of 4.145 that the products offered by MFIs are highly differentiated. This is line with Sidek (2013) observations that product innovation indeed significantly influences firm performance.

\section{Process Innovation on Performance of Microfinance Institution}

The opinions of the respondents in relation to process innovation on performance of microfinance institutions are outlined in Table 4.

Table 4: Process Innovation on Performance of Microfinance Institution

\begin{tabular}{|l|l|l|l|l|l|l|l|l|}
\hline & $\begin{array}{l}\text { Strongly } \\
\text { Agree }\end{array}$ & Agree & Indifferent & Disagree & $\begin{array}{l}\text { Strongly } \\
\text { Disagree }\end{array}$ & Max & Min & Mean \\
\hline $\begin{array}{l}\text { MFIs have a well- } \\
\text { articulated process } \\
\text { design. }\end{array}$ & $31(50)$ & $19(31)$ & $7(11)$ & $5(8)$ & $0(0)$ & 5 & 1 & 4.226 \\
\hline $\begin{array}{l}\text { MFIs have enacted } \\
\text { changes in provision of } \\
\text { services. }\end{array}$ & $34(55)$ & $26(42)$ & $2(3)$ & $0(0)$ & $0(0)$ & 5 & 1 & 4.516 \\
\hline $\begin{array}{l}\text { MFIs have adopted a } \\
\text { cost effective process of } \\
\text { operations. }\end{array}$ & $41(66)$ & $21(34)$ & $0(0)$ & $0(0)$ & $0(0)$ & 5 & 1 & 4.532 \\
\hline $\begin{array}{l}\text { The delivery process in } \\
\text { MFIs is up to date. }\end{array}$ & $32(52)$ & $30(48)$ & $0(0)$ & $0(0)$ & $0(0)$ & 5 & 1 & 4.387 \\
\hline $\begin{array}{l}\text { MFIs have automated } \\
\text { their service delivery. }\end{array}$ & $28(45)$ & $31(50)$ & $3(5)$ & $0(0)$ & $0(0)$ & 5 & 1 & 4.403 \\
\hline
\end{tabular}

According to the findings, the respondents indicated with a mean of 4.226 that MFIs have a wellarticulated process design. They also indicated with a mean of 4.516 that MFIs have enacted changes in provision of services. They further indicated with a mean of 4.532 that MFIs have adopted a cost effective process of operations. In addition, the respondents indicated with a mean of 4.387 that the delivery process in MFIs is up to date. Finally, the respondents indicated with a mean of 4.403 that MFIs have automated their service delivery. The study agree with Mabrouk and Mamoghli (2010) who states that if process innovation is continued and new technologies are introduced then innovative banks continue to earn high profits.

\section{Performance}

Lastly, the respondents were asked to indicate their level of agreement or disagreement regarding performance of microfinance institution Table 5.

Table 5: Performance

\begin{tabular}{|l|l|l|l|l|l|l|l|l|}
\hline & $\begin{array}{l}\text { Strongly } \\
\text { Agree }\end{array}$ & Agree & Indifferent & Disagree & $\begin{array}{l}\text { Strongly } \\
\text { Disagree }\end{array}$ & Max & Min & Mean \\
\hline MFIs enjoys high profits. & $29(47)$ & $21(34)$ & $8(13)$ & $4(6)$ & $0(0)$ & 5 & 1 & 4.210 \\
\hline $\begin{array}{l}\text { MFIs have recorded increased } \\
\text { return on assets over the past } \\
\text { financial year. }\end{array}$ & $31(50)$ & $19(31)$ & $9(15)$ & $3(5)$ & $0(0)$ & 5 & 1 & 4.258 \\
\hline
\end{tabular}


Effect Of Financial Innovations On Performance Of Microfinance Institutions In Nakuru Town,..

\begin{tabular}{|l|l|l|l|l|l|l|l|l|}
\hline $\begin{array}{l}\text { MFIs have advanced more } \\
\text { cumulative loans over the last year } \\
\text { compared to previous years. }\end{array}$ & $27(44)$ & $33(53)$ & $2(3)$ & $0(0)$ & $0(0)$ & 5 & 1 & 4.403 \\
\hline $\begin{array}{l}\text { MFIs have continued to record } \\
\text { decreasing non-performing loans. }\end{array}$ & $23(37)$ & $27(44)$ & $10(16)$ & $2(3)$ & $0(0)$ & 5 & 1 & 4.177 \\
\hline $\begin{array}{l}\text { MFIs enjoy high return on } \\
\text { investment. }\end{array}$ & $31(50)$ & $28(45)$ & $3(5)$ & $0(0)$ & $0(0)$ & 5 & 1 & 4.500 \\
\hline $\begin{array}{l}\text { MFIs realize high return on } \\
\text { equity. }\end{array}$ & $32(52)$ & $28(45)$ & $2(3)$ & $0(0)$ & $0(0)$ & 5 & 1 & 4.484 \\
\hline
\end{tabular}

According to the findings, the respondents indicated with a mean of 4.210 that MFIs enjoys high profits. They also indicated with a mean of 4.258 that MFIs have recorded increased return on assets over the past financial year. They further indicated with a mean of 4.403 that MFIs have advanced more cumulative loans over the last year compared to previous years. In addition, the respondents indicated with a mean of 4.177 that MFIs have continued to record decreasing non-performing loans. The findings also revealed that MFIs enjoy high return on investment with a mean 4.500. Finally, the respondents indicated with a mean of 4.484 that MFIs realize high return on equity.

\section{Regression Analysis}

The study evaluated how the financial innovation under study (institutional innovation, product innovation and process innovation) influenced performance of microfinance institutions in Nakuru town. Using multiple regression analysis and Analysis of Variance (ANOVA), the combined effect of institutional innovation, product innovation and process innovation on performance of microfinance institutions was established.

The R-Squared is the proportion of variance in the dependent variable which can be explained by the independent variables. The R-squared in this study was 0.672 , which shows that the three independent variables (institutional innovation, product innovation and process innovation) can explain $67.2 \%$ of performance of microfinance institutions while other factors explain $32.8 \%$.

Table 6: Model Summary

\begin{tabular}{|l|l|l|l|l|}
\hline Model & R & R Square & Adjusted R Square & Std. Error of the Estimate \\
\hline 1 & 0.7563 & 0.67199 & 0.52761 & 2.56741 \\
\hline
\end{tabular}

The analysis of variance in this study was used to determine whether the model was a good fit for the data. From the findings, the p-value was 0.000 which is less than the conventional 0.05 and hence the model was good in predicting how the three independent variables (institutional innovation, product innovation and process innovation) influence performance of microfinance institutions.

Table 7: Analysis of Variance

\begin{tabular}{|l|l|l|l|l|l|l|}
\hline \multicolumn{2}{|l|}{ Model } & Sum of Squares & df & Mean Square & F & Sig. \\
\hline \multirow{4}{*}{1} & Regression & 23.7930 & 4 & 5.9483 & 67.1956 & 0.000 \\
\cline { 2 - 7 } & Residual & 14.4290 & 163 & 0.0885 & & \\
\cline { 2 - 7 } & Total & 38.2220 & 167 & & & \\
& & & & & \\
\end{tabular}

Further, the F-calculated (67.1956) was more than the $\mathrm{P}(0.05)$ which shows that the model was fit in predicting the influence of the independent variables on the dependent variable.

Table 8: Regression Coefficients

\begin{tabular}{|l|l|l|l|l|l|}
\hline & \multicolumn{2}{l}{$\begin{array}{l}\text { Unstandardized } \\
\text { Coefficients }\end{array}$} & $\begin{array}{l}\text { Standardized } \\
\text { Coefficients }\end{array}$ & \multirow{2}{*}{ Sig. } \\
\cline { 2 - 5 } & B & Std. Error & Beta & & \\
\hline (Constant) & 6.797 & 2.024 & & 3.358 & 0.000 \\
\hline Institutional innovation & 0.454 & 0.091 & 0.345 & 4.989 & 0.000 \\
\hline Product innovation & 0.213 & 0.085 & 0.198 & 2.506 & 0.021 \\
\hline Process innovation & 0.385 & 0.120 & 0.235 & 3.208 & 0.000 \\
\hline
\end{tabular}

The interpretations of the findings indicated the following regression model.

$Y=\beta_{0}+\beta_{1} X_{1}+\beta_{2} X_{2}+\beta_{3} X_{3}+\varepsilon$

Therefore,

\section{$Y=6.767+0.454 X_{1}+0.213 X_{2}+0.385 X_{3}$}

From the findings, there is a positive significant relationship between institutional innovation and performance of microfinance institutions in Nakuru town as shown by a regression coefficient of 0.454 . The $\mathrm{p}$ value (0.000) was less than the significance level (0.05), hence the relationship was significant. The results also 
indicate that there is a positive relationship between product innovation and performance of microfinance institutions in Nakuru town as shown by a regression coefficient of 0.235 . The relationship was found to be significant as the p-value (0.021) was less than the significance level (0.05). Lastly, the results show that there is a positive significant relationship between process innovation and performance of microfinance institutions in Nakuru town as shown by a regression coefficient of 0.385 . This relationship was significant as the p-value $(0.000)$ was less that of the significance level (0.05).

Out of the three factors investigated, Institutional innovation and Process innovation were the most important since to generate one unit of performance, 0.454 units of institutional innovation and 0.385 units of process innovation must be increased. Therefore Micro finance institutions firms ought to focus more on institutional innovation and process innovation.

\section{Conclusions}

From the findings the researcher concluded that there is a supervisory framework that monitors MFIs. Some of the innovations observed by MFIs in mobile banking include partnerships, financial trainings, branch networking and opening up new branches. It is was also concluded that innovations can be a source of competitive advantage if a firm understands customer needs, competitors' actions and technological development and act accordingly to stay at par with rivals. Organizational innovation positively enhances business performance when they examined organizational innovation, transformational leadership, knowledge management, organizational learning and organizational performance in Malaysian companies.

In relation to the second objective, it can be concluded that product performance is relatively high compared to other financial institutions. Products offered by MFIs are also highly differentiated. Product innovations dimensions in terms of new products, improved products, and quality products largely and positively influence firm performance. Innovation enhances firm performance by strategically placing a firm in the market. On the third objective, it can be concluded that the delivery process in MFIs is up to date. MFIs have automated their service delivery. Process innovation besides enhancing speed and quality result to flexibility and cost efficiency. Process enhances speed and quality result to flexibility and cost efficiency

\section{Recommendations}

In the light of the foregoing findings, the study recommends that in-order to enhance firm performance the management of microfinance ought to focus on the firm activities aligned towards renewing routines, procedures and processes in an innovative manner in a firm. This will positively improve the performance of microfinance. The study also recommended that MFIs ought to develop unique micro MFIS products and other loan and service product in order to meet the rising demands of the poor and the marginalized who cannot afford the current packages offered by the institutions. It is also important that in order to enhance profitability MFIs should focus more on process innovation, like mobile banking this will have a significant relationship to performance of MFIs.

\section{References}

[1]. Chemitei, L.J. (2012).The role of product innovations in creating competitive advantage: A case of microfinance institutions in Nakuru town. Unpublished MBA project, Kabarak University, Kenya.

[2]. Kariuki, F.W. (2010). The relationship between financial engineering and financial performance of commercial banks in Kenya.Unpublished MBA project, University of Nairobi, Nairobi, Kenya.

[3]. Kothari, R. (2008). Research methodology: Methods and techniques. New Delhi: New $\quad$ Age International (P) Limited publishers.

[4]. Mabrouk,A.,\&Mamoghli C. (2010).Is financial innovation influenced by financial liberalization? Evidence from the Tunisian banking industry.Banks Systems Journal, 5(3), 45-50.

[5]. Mugenda, O. M., \&Mugenda, A. G. (2003).Research Methods: Quantitative and Qualitative Approaches. Nairobi: Acts Press.

[6]. Mugo, J.G. (2012).The effect of financial innovation on the growth of micro-finance Institutions in Kenya. Unpublished MBA project, University of Nairobi, Kenya.

[7]. Mwangi, J.M. (2014). The Effect of Financial Innovation of Financial Returns of Deposit Taking Microfinance Institutions in Kenya.MBA research project, University of Nairobi, Kenya.

[8]. Mytelka, L. K. (2000). Local systems of innovation in a globalized world economy. Industry and Innovation, 7(1), 15-32. 